\title{
Atypical Antipsychotic Induced Weight Gain in Schizophrenic Patients
}

\author{
Tetie Herlina ${ }^{1}$, Dyah A. Perwitasari ${ }^{2}$, Haafizah Dania ${ }^{2}$, Santi Yuliani ${ }^{3}$, Melisa I. Barliana ${ }^{4}$ \\ ${ }^{1}$ Master of Pharmacy, Universitas Ahmad Dahlan, Yogyakarta, Indonesia, \\ ${ }^{2}$ Faculty of Pharmacy, Universitas Ahmad Dahlan, Yogyakarta, Indonesia, \\ ${ }^{3}$ Prof. Dr. Soerojo Mental Hospital, Magelang, Indonesia, ${ }^{4}$ Faculty of Pharmacy, \\ Universitas Padjadjaran, Sumedang, Indonesia
}

\begin{abstract}
Atypical antipsychotics are widely prescribed and have the potential to cause weight gain, which may result in the development of metabolic syndrome. Also, it is important to monitor the use of atypical antipsychotic for metabolic disturbance. The purpose of this study is to determine the side effects of atypical antipsychotics in increasing body weight in schizophrenia patients after 4 weeks of use. Furthermore, a retrospective design was conducted and data were collected based on consecutive sampling in 80 adult psychiatric inpatients $(20$ women and $60 \mathrm{men})$ with initial diagnoses of schizophrenia and with the same daily nutrition. The patients were hospitalized from January to March 2019, within the term (over 4 weeks) of initiation atypical antipsychotic. The patient body weight was collected before and 4 weeks after the treatment of atypical antipsychotic. The results showed that patients $(20$ women and 60 men) receiving atypical antipsychotic had a mean age of 35.6 years and a percentage of $70 \%$ women and $56 \%$ men had a weight gain of $1-5 \mathrm{~kg}$ over 4 weeks. The mean weight observed among our subjects increased from $57.55 \pm 10.743 \mathrm{~kg}$ to $59.83 \pm 12.205 \mathrm{~kg}$ after initiating treatment $(\mathrm{p}=0.001)$. However, the dual combination of atypical antipsychotics risperidone and clozapine are the most widely atypical antipsychotic used with a percentage equal to $91.25 \%, 3.75 \%$ clozapine, and $5 \%$ risperidone. Furthermore, it can be concluded that atypical antipsychotics use for at least 4 weeks can cause weight gain in schizophrenic patients. Pharmacist and doctors are recommended to monitor the metabolic side effects due to the atypical antipsychotic use.
\end{abstract}

Keywords: Atypical antipsycotic, schizophrenia, weight gain

\section{Antipsikotik Atipikal Menginduksi Peningkatan Berat Badan pada Pasien Skizofrenia}

\begin{abstract}
Abstrak
Antipsikotik atipikal banyak diresepkan dan berpotensi menyebabkan kenaikan berat badan yang dapat menyebabkan sindrom metabolik. Ada kebutuhan klinis yang mendesak untuk memantau penggunaan antipsikotik atipikal terhadap gangguan metabolisme. Penelitian ini bertujuan untuk mengetahui efek samping antipsikotik atipikal dalam meningkatkan berat badan pada pasien skizofrenia setelah pemakaian 4 minggu. Melalui desain retrospektif, data dikumpulkan dengan consecutive sampling pada 80 pasien rawat inap psikiatri dewasa (20 wanita dan 60 pria) dengan diagnosis awal skizofrenia dan dengan pengaturan nutrisi harian yang sama. Pasien dirawat di rumah sakit sejak Januari 2019 sampai dengan Maret 2019, dalam jangka menengah (lebih dari 4 minggu) pemberian antipsikotik atipikal. Data berat badan pasien dicatat sebelum dan 4 minggu sesudah pemakaian antipsikotik atipikal. Pasien (20 wanita dan 60 pria) yang menerima antipsikotik atipikal memiliki usia rata-rata 35,6 tahun, semua pasien dengan persentase $70 \%$ wanita dan $56 \%$ pria memiliki kenaikan berat badan $1-5 \mathrm{~kg}$ selama periode 4 minggu. Berat rata-rata yang diamati di antara subyek meningkat dari $57,55 \pm 10,743 \mathrm{~kg}$ menjadi $59,83 \pm 12,205 \mathrm{~kg}$ setelah memulai pengobatan $(\mathrm{p}=0,001)$. Antipsikotik atipikal yang paling banyak digunakan adalah kombinasi antipsikotik atipikal risperidon clozapin dengan persentase sebesar $91,25 \%$, clozapin 3,75\%, risperidon 5\%. Kami menyimpulkan bahwa penggunaan antipsikotik atipikal selama setidaknya 4 minggu dapat menyebabkan penambahan berat badan pada pasien skizofrenia. Apoteker dan dokter direkomendasikan untuk memantau efek samping metabolik akibat penggunaan antipsikotik atipikal.
\end{abstract}

Kata kunci: Antipsikotik atipikal, peningkatan berat badan, skizofrenia

Correspondence: Prof. Dr. apt. Dyah A. Perwitasari, M.Si., Ph.D., Faculty of Pharmacy, Universitas Ahmad Dahlan, Yogyakarta, Special Region of Yogyakarta 55164, Indonesia, email: dyah.perwitasari@pharm.uad.ac.id Submitted: $11^{\text {th }}$ September 2019, Accepted: $11^{\text {th }}$ March 2021, Published: $30^{\text {th }}$ March 2021 


\section{Introduction}

Schizophrenia is a serious mental condition that affects $1 \%$ of the general population and its treatment usually causes various side effects. Atypical antipsychosis is the second generation of antipsychosis that has been developed and used to treat symptoms of scizophrenia. Examples of atypical antipsychoses include olanzapine, clozapin, and risperidone. ${ }^{1}$

People with scizophrenia are twice as likely to die than normal people due to cardiovascular disease and decrease more than 20 years of life expectancy. ${ }^{1}$ Antipsychotic drugs reduce hallucinations and delusions in patients with scizophrenia especially bipolar schizophrenia. ${ }^{2}$ Atypical antipsychotics are the first-line treatment of schizophrenia and rare classified as based on the side effects of extrapyramidal syndrome and tardive dyskinesia. ${ }^{3}$ Typical antipsychotics are rarely used, and are replaced with atypical antipsychotics due to smaller extrapyramidal side effects and tardive dyskinesia. ${ }^{2}$

Meta-analysis reported that antipsychotics cause various cardiovascular diseases compared to placebo and it is also reported that $35.3 \%$ of patients who got atypical antipsychotics got metabolic syndrome. ${ }^{4}$ Significant weight gain occured after 6-8 weeks atypical antipsychotic use and in other studies also found patterns of weight gain after 47 days of initial use of olanzapine and risperidone..$^{5,6}$

A study conducted in an Indonesian hospital showed that the most widely prescribed antipsychotic was risperidone with a percentage of $35.71 \% .^{7}$ Another study in Indonesia showed that the percentage of use of the atypical combination of antipsychotic risperidone clozapine in schizophrenic patients was $43.4 \%{ }^{8}$ In addition, a cross-sectional analytic descriptive study was conducted in psychiatric patients treated at Bali Provincial
Mental Hospital from January 2018 to February 2018. There was a high prevalence of metabolic syndrome (MS) among patients with mental disorder. A total of 245 samples were included in this study with the prevalence of MS was $48.6 \%$. According on sex, female had higher proportion among MS patients than male (42.8\% vs $60.7 \%) .{ }^{9}$ The objective of this study was to determine the side effects of atypical antipsychotic in increasing body weight in schizophrenia patients.

\section{Methods}

Through retrospective design, body weight data before and after 4 weeks treatment with atypical antipsychotic were collected on 80 adult psychiatric inpatients ( 20 women and 60 men) diagnosed with schizophrenia. Ethical clearance of this study was issued by Prof. Dr. Soerodjo Mental Hospital Ethics and Legal Committee with the number KEH/004/ $\mathrm{XI} / 2018$. The patients were hospitalized at Prof. Dr. Soerojo Mental Hospital Magelang from January, 2019 to March, 2019, within medium term (over 4 weeks) of initiation atypical antipsychotic.

The inclusion criteria for this study sample were patients with an initial diagnosis of schizophrenia, patients with a history of combination or single therapy of atypical antipsychotic for at least 1 month, female and male patients aged 18 years and over. Meanwhile, the exclusion criteria in this study were schizophrenic patients who entered the inclusion criteria but were excluded in the study because treatment is stopped or did not reach the minimum treatment time, which is 1 month, data of the treatment profile and supporting examination in the medical record were incomplete (the required data is not listed or is illegible), patients with additional diagnosis type 2 diabetes mellitus and/or hypertension and/or disilipidemia at the time of administration atypical antipsychotic 
therapy, patients taking oral antidiabetic (OAD) or insulin and/or anti-hypertension and/or lipid-lowering drugs at the time of administration antipsychotic therapy. Data on diagnosis, drug use, and patients' body weight were taken from medical records. Data on body weight before and 4 weeks after treatment with atypical antipsychotic were analyzed using Wilcoxon analysis.

\section{Results}

Results of the 80 patients receiving atypical antipsychotic shows that the mean age was 35.6 years, and $70 \%$ female and $56 \%$ male patients gained $1-5 \mathrm{~kg}$ in weight over a period of 4 weeks. The most widely atypical antipshycotic used was combination dual atypical antipshycotic risperidone-clozapine with a percentage equal to $91.25 \%, 3.75 \%$ clozapine, and 5\% risperidone. The patients' characteristics can be seen in Table 1.

Table 2 shows weight gain during atypical antipsychotic therapy of 80 adult psychiatric inpatients diagnosed with schizophrenia within medium term (over 4 weeks) of initiation of atypical antipsychotic. After Wilcoxon analysis was performed, it was found that there was significant association between the use of atypical antipsychotic and patients' weight gain. The mean weight observed among the subjects increased from $57.55 \pm 10.743 \mathrm{~kg}$ to $59.83 \pm 12.205 \mathrm{~kg}$ after initiating treatment $(\mathrm{p}=0.001)$.

\section{Discussion}

The most widely atypical antipshycotic used was combination dual atypical antipshycotic risperidone-clozapine with a percentage equal to $91.25 \%, 3.75 \%$ clozapine, and $5 \%$ risperidone. All patients obtained nutrition controlled by the calculation of calorie needs by nutritionists in the hospital.

The use of antipsychotic combinations was commonly given to patients in order to stabilize the disease and to achieve a greater therapeutic response when the therapeutic response to a single antipsychotic was not responsive. However, the use of a combination of antipsychotics including prescribing higher total doses is feared to increase the risk of side effects. For schizophrenic patients who are resistant to treatment that is not responsive to single clozapine, the administration of second antipsychotic as addition will be an alternative therapy. Adding other antipsychotics with clozapine increases the level of dopamine

Table 1 Patients' Demographic

\begin{tabular}{|c|c|c|c|}
\hline Variable & $\begin{array}{c}\text { Total }(\mathbf{N}=80) \\
\mathbf{n}(\%)\end{array}$ & $\begin{array}{c}\text { With Weight Gain }(\mathrm{N}=48) \\
\mathrm{n}(\%)\end{array}$ & $\begin{array}{l}\text { Without Weight Gain }(\mathbf{N}=32) \\
\text { n(\%) }\end{array}$ \\
\hline Age $(X \pm S D)$ & $35.6 \pm 7.815$ & $36.25 \pm 6.715$ & $35.10 \pm 8.645$ \\
\hline \multicolumn{4}{|l|}{ Smoking } \\
\hline Yes & $48(60)$ & $26(54)$ & $22(46)$ \\
\hline No & $32(40)$ & $22(69)$ & $10(31)$ \\
\hline \multicolumn{4}{|l|}{ Sex } \\
\hline Male & $60(75)$ & $34(56)$ & $25(44)$ \\
\hline Female & $20(25)$ & $14(70)$ & $6(30)$ \\
\hline \multicolumn{4}{|l|}{ Therapy } \\
\hline Combination & $73(91.25)$ & $44(60.74)$ & $29(39.73)$ \\
\hline Single & $7(8.75)$ & $4(57.14)$ & $3(42.86)$ \\
\hline \multicolumn{4}{|c|}{ Duration of Therapy } \\
\hline 1-3 month & $35(43.75)$ & $20(57.14)$ & $15(42.86)$ \\
\hline$>3$ month & $45(56.25)$ & $27(60)$ & $18(40)$ \\
\hline
\end{tabular}


Table 2 Patients' Weight Gain According to Atypical Antipsychotic Therapy $(\mathrm{n}=\mathbf{8 0})$

\begin{tabular}{lcc}
\hline & Mean & SD \\
\hline Body weight baseline & 57.55 & 10.743 \\
Body weight after initiation therapy $(\mathrm{p}=0.001)$ & 59.83 & 12.205 \\
\hline
\end{tabular}

receptor D2. However, this increase may also be related to an increase in extrapyramidal symptopms (EPS) risk. ${ }^{10}$

The most serious side effect of using atypical antipsychotic drugs is obesity ${ }^{11}$ and MS which causes an increased risk of cardiovascular disease. ${ }^{12}$ The metabolic rate of the syndrome increases over time as the use of atypical antipsychotics increases. Patients starting therapy with atypical antipsychotics have a three times higher chance of metabolic syndrome. Patients who get olanzapin have a prevalence of MS of 20-25\%, risperidone 9-24\%, and haloperidol 9\%. Another study reported that outpatients with schizophrenia and schizoaffective receiving clozapine had MS with prevalence of 20-25\%, followed by risperidone $9-24 \%$ and haloperidol $0-3 \% .^{13}$

The relationship between female sex and obesity in schizophrenic patients is caused by many factors. This can be resulted from the differences in pharmacokinetics between male and female patients, CYP450 enzyme activity which can cause differences plasma concentrations, and therapeutic profiles and concentrations of antipsychotics such as olanzapine and clozapine. Research with a larger population is needed to see the effect and mechanism of increasing body weight on gender. ${ }^{14}$

This study has several limitations. First, the influence of independent variables (such as patients' demographic data and nutritional intake of patients before therapy) towards weight gain cannot be analyzed since this study was conducted retrospectively. Second one was the limited number of samples in our study which was due to frequent replacement of treatment regimens.

\section{Conclusion}

Atypical antipsychotics use for at least 4 weeks can cause weight gain in schizophrenic patients. Pharmacist and doctors are recommended to monitor the metabolic side effects due to the atypical antipsychotic use.

\section{Acknowledgement}

The authors thank Prof. Dr. Soerodjo Mental Hospital, Magelang, Indonesia, for approval and funding to complete this study.

\section{Funding}

This study was funded by Institute of Research and Community Service (LPPM) Universitas Ahmad Dahlan through internal research funding 2018.

\section{Conflict of Interest}

The authors have none to declare.

\section{References}

1. Sriretnakumar V, Huang E, Müller DJ. Pharmacogenetics of clozapine treatment response and side-effects in schizophrenia: An update. Expert Opin Drug Metab Toxicol. 2015;11(11):1709-31. doi: 10. $1517 / 17425255.2015 .1075003$

2. Meltzer HY. Update on typical and atypical antipsychotic drugs. Annu Rev Med. 2013;64(1):393-406. doi: 10.1146/ annurev-med-050911-161504

3. Vasudev K, Choi Y-H, Norman R, Kim RB, Schwarz UI. Genetic determinants of 
clozapine-induced metabolic side effects. Can J Psychiatry. 2017;62(2):138-49. doi: 10.1177/0706743716670128

4. Mitchell AJ, Vancampfort D, De Herdt $\mathrm{A}, \mathrm{Yu} \mathrm{W}, \mathrm{De}$ Hert M. Is the prevalence of metabolic syndrome and metabolic abnormalities increased in early schizophrenia? A comparative metaanalysis of first episode, untreated and treated patients. Schizophr Bull. 2013;39 (2):295-305. doi: 10.1093/schbul/sbs082

5. Foley DL, Morley KI. Systematic review of early cardiometabolic outcomes of the first treated episode of psychosis. Arch Gen Psychiatry. 2011;68(6):609-16. doi: 10.1001/archgenpsychiatry.2011.2

6. Correll CU, Robinson DG, Schooler NR, Brunette MF, Mueser KT, Rosenheck $\mathrm{RA}$, et al. Cardiometabolic risk in patients with first-episode schizophrenia spectrum disorders: Baseline results from the RAISE-ETP study. JAMA Psychiatry. 2014;71(12):1350-63. doi: 10.1001/jama psychiatry.2014.1314

7. Aryani F, Sari O. Gambaran pola penggunaan antipsikotik pada pasien skizofrenia di ruang rawat inap rumah sakit jiwa. J Manaj Pelayan Farm. 2016;6(1):35-40. doi: 10.22146/jmpf.236

8. Indriani A, Ardiningrum W, Febrianti Y. Studi penggunaan kombinasi antipsikotik pada pasien skizofrenia di rumah sakit Yogyakarta. Maj Farmaset. 2019;4(1): 201-11. doi: 10.24198/mfarmasetika.v4i 0.25882

9. Prebawa IPAG, Witari PK, Ariawan, IWY. Gambaran sindrom metabolik pada pasien gangguan jiwa yang dirawat di rumah sakit jiwa provinsi Bali. Intisari Sains Medis. 2019;10(2):459-64. doi: 10. 1556/ism.v10i2.456

10. Cooper SJ, Reynolds GP, Barnes T, England E, Haddad PM, Heald A, et al. BAP guidelines on the management of weight gain, metabolic disturbances and cardiovascular risk associated with psychosis and antipsychotic drug treatment. J Psychopharmacol. 2016;30(8):717-48 doi: 10.1177/0269881116645254

11. Gregoor JG, Mulder H, Cohen D, van Megen HGJM, Egberts TCG, Heerdink ER, et al. Combined HTR2C-LEP genotype as a determinant of obesity in patients using antipsychotic medication. $\mathrm{J}$ Clin Psychopharmacol. 2010;30(6):7025. doi: 10.1097/JCP.0b013e3181fa05a2

12. Puangpetch A, Unaharassamee W, Jiratjintana N, Koomdee N, Sukasem C. Genetic polymorphisms of HTR2C, LEP and LEPR on metabolic syndromes in patients treated with atypical antipsychotic drugs. J Pharm Pharmacol. 2018;70(4):536-42. doi: 10.1111/jphp.1 2892

13. Kraemer S, Minarzyk A, Forst T, Kopf D, Hundemer H-P. Prevalence of metabolic syndrome in patients with schizophrenia, and metabolic changes after 3 months of treatment with antipsychotics--results from a German observational study. BMC Psychiatry. 2011;11(1):173. doi: 10. 1186/1471-244X-11-173

14. Castellani LN, Costa-Dookhan KA, Mclntyre WB, Wright DC, Flowers SA, Hahn MK, et al. Preclinical and clinical sex differences in antipsychotic-induced metabolic disturbances: A narrative review of adiposity and glucose metabolism. J Psychiatr Brain Sci. 2019;4:e190013. doi: 10.20900/jpbs.20190013

(C) 2021 Herlina et al. The full terms of this license incorporate the Creative Common Attribution-Non Commercial License (https://creative commons.org/licenses/by-nc/4.0/). By accessing the work you hereby accept the terms. Non-commercial use of the work are permitted without any further permission, provided the work is properly attributed. 